\title{
Knowledge of the Farmers about Low Cost Greenhouse Technology
}

\author{
C.D. Chauhan ${ }^{1 *}$, M.R. Bhatt ${ }^{1}$, V.S. Parmar ${ }^{1}$ and J.M. Charel ${ }^{2}$ \\ ${ }^{1}$ Department of extension education, NAU, Navsari, India \\ ${ }^{2}$ College of Agriculture, JAU, Amreli, India \\ *Corresponding author
}

\section{A B S T R A C T}

Keywords

Low cost technology, Low cost green house, Knowledge, precision farming

Article Info

\section{Accepted:} 04 April 2017 Available Online: 10 May 2017
Low cost technology offers an excellent opportunity to grow high value crops during off-season with maximum input use efficiency. This has special relevance in the present day scenario of shrinking land and water resources. At Precision Farming Development Centre, NAU, Navsari technologies related to protected cultivation have been developed. These comprise of basically low (naturally ventilated) and medium cost (fan pad cooling system) greenhouses, in which former type does not require power supply or cooling mechanism. Navsari district of South Gujarat was chosen purposively for the study. For this study 100 farmers were considered as a sample and termed in this study as respondents. To know the various characteristics of the respondents a structured schedule was developed. Majority of the respondents had medium level of knowledge about low cost greenhouse technology.

\section{Introduction}

Low cost Greenhouse Technology is the technique of providing favorable environmental condition to the plants. It is rather used to protect the plants from the adverse climatic conditions such as wind, cold, precipitation, excessive radiation, extreme temperature, insects and diseases. It is also of vital importance to create an ideal micro climate around the plants. This is possible by erecting a greenhouse / glass house, where the environmental conditions are so modified that one can grow any plant in any place at any time by providing suitable environmental conditions with minimum labour. Greenhouses are framed or inflated structures covered with transparent or translucent material large enough to grow crops under partial or full controlled environmental conditions to get optimum growth and productivity. Greenhouse structure of various types is used for crop production. Based on the cost of construction involved greenhouse classified as (i) High cost Greenhouse, (ii) Medium cost Greenhouse, (iii) Low cost Greenhouse. Low cost greenhouse technology has a good potential in rural area for income generating and livelihood security.

Low cost green house could be easily made from locally available resources. Adaptation of low cost greenhouse technologies to Indian 
conditions will undoubtedly lead to increased opportunities for production of high value plants and materials in areas where the environment is extremely harsh. Low cost green house cultivation also has the potential benefit of substantially increasing plant productivity per unit water consumption. Also gives higher yield, year round production of crops, disease-free and genetically superior transplants can be produced continuously, efficient utilization of chemicals and pesticides, water requirement is limited, hardening of tissue cultured plants, production of quality produce free of blemishes, most useful in monitoring and controlling the instability of various ecological system, modern techniques of hydroponic (Soil less culture), aeroponics and nutrient film techniques are possible only under greenhouse cultivation.

Government started special scheme for low cost green house under National Horticulture Mission. To adopt such technology to motivate the farmer's governments specially give subsidies in low cost green house. Under the National Horticulture Mission and RKVY in Navsari district all talukas were covered for low cost greenhouse technology scheme. But, the adoption pace of this technology is very low. It is very important in this situation to know the knowledge of farmers about low cost Greenhouse technology.

Considering the scanty researches and prevailing facts about present study, an effort in this direction was made by planning and conducting a study on "Knowledge of Farmers towards Low Cost Greenhouse Technology" with following objective; To measure the knowledge level of the respondents about low cost Greenhouse technology. And also Ascertain the relationship between knowledge of farmers with their personal characteristic.

\section{Materials and Methods}

Soil and Water Research Management unit of Navsari Agricultural University this university has do enough research on the low cost greenhouse technology. Maximum number of Navsari district farmers adopted this technology under RKVY and NHM projects of Government of Gujarat state. So, Navsari district of South Gujarat was chosen as purposively for the study. Navsari district is consisting of six taluaks viz., Navsari, Jalalpore, Chikhli, Khergam, Gandevi and Vansda. Out of these two talukas viz, Vansda and Chikhli taluka has maximum number of low cost Greenhouse holder, so this two talukas were selected purposively. Further, purposive sampling technique was followed for selection of villages from each selected talukas. Five villages from each talukas were selected in which maximum number of greenhouse holders are residing. Thus, the total ten villages were selected for this study. Simple random sampling technique was followed for selection of respondents from each selected village. Ten farmers from each village were selected randomly. Thus, total 100 respondents of low cost greenhouse technology were selected as respondents.

Ex-post-facto research design was used in the present investigation. For this study 100 farmers were considered as a sample and termed in this study as respondents. To know the various characteristics of the respondents a structured schedule was developed. For measuring age, education, size of family, size of land holding, occupation, annual income, social participation overall modernity, scientific orientation, economic motivation and risk orientation scale developed by Pandya (2010), Inkeles (1996) and Supe (1969) was used with slight modifications. A simple ranking technique was applied to measure the opinion of the respondents. The data were collected with the help of well- 
structured, pre-tested, Gujarati version interview scheduled through personal contact and data were compiled, tabulated and analyzed to get proper answers for objectives of the study. The statistical tools used were percentage, mean score and standard deviation.

\section{Knowledge level about low cost greenhouse technology}

Knowledge about low cost green house technology was measured with the help of teacher made knowledge test following the technique suggested by Jha and Singh (1970). The knowledge index for each respondent was calculated with help of following formula:

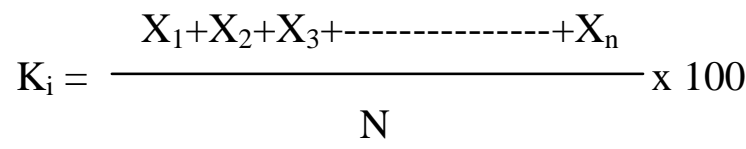

Where,

$\mathrm{K}_{\mathrm{i}}=$ Knowledge index .

$\mathrm{X}_{1}, \mathrm{X}_{2}, \mathrm{X}_{3^{-----} \mathrm{X}_{\mathrm{n}}=\text { Total number of correct }}$ answers, i.e. Total score.

$\mathrm{N}=$ Total number of items in the test.

The respondents were grouped in to three level of knowledge on the basis of knowledge index by using mean and standard deviation

\begin{tabular}{|c|lr|c|}
\hline Sr. no. & \multicolumn{1}{|c|}{ Categories } & Range \\
\hline 1. & Low level knowledge & $\begin{array}{c}<\text { Mean }- \\
\text { SD }\end{array}$ \\
\hline 2. & $\begin{array}{l}\text { Medium } \\
\text { knowledge }\end{array}$ & $\begin{array}{c}\text { levelween } \\
\text { bean } \pm \text { SD }\end{array}$ \\
\hline 3. & $\begin{array}{l}\text { High } \\
\text { knowledge }\end{array}$ & $\begin{array}{c}\text { Mean }+ \\
\text { SD }\end{array}$ \\
\hline
\end{tabular}

\section{Results and Discussion}

Knowledge level of the respondents about low cost greenhouse technology

An attempt has been made to assess the knowledge level of respondents about low cost greenhouse technology. The teacher made tests was developed with thirteen items to assess the knowledge level of the farmers. A score of 'one' was assigned to correct answer and 'zero' for incorrect answer. On the basis of score obtained, the respondents were categorized in to three categories. Table 2 indicates the results in this regard.

The results in table 2 postulated that nearly two third (61.00 per cent) of the respondents were having medium level of knowledge, followed by 22.00 per cent of them who had low level of knowledge and 17.00 per cent of respondents had high level of knowledge. From table 1, it could be inferred that more than three forth $(78.00$ per cent) of the respondent posses knowledge from middle to higher level. The probable reason might be that they are directly connected with Krishi vigyan, soil and water management unit of Navsari and getting the information from their scientist. This finding of present study is supported by Yadav et al., (2014), Dhola and Thumar (2012).

\section{Relationship between knowledge of farmers with their personal characteristic}

The information about association between independent characters and level of knowledge is depicted in table 3 and figure 1 with empirical model figure 2 .

It can be concluded from table 3 that size of family $\left(0.021^{\mathrm{ns}}\right)$, farming experience $\left(0.117^{\mathrm{ns}}\right)$, and overall modernity $\left(0.139^{\mathrm{ns}}\right)$ were positively but non-significantly correlated with knowledge about low cost greenhouse technology. 
Table.1 Information about taluka and villages covered under the study

\begin{tabular}{|c|c|c|c|}
\hline Sr. no & Talukas & Villages & Respondent Selected \\
\hline \multirow[t]{5}{*}{1} & \multirow[t]{5}{*}{ Vansda } & Limzer & 10 \\
\hline & & Boriachh & 10 \\
\hline & & Navanagar & 10 \\
\hline & & Gangpur & 10 \\
\hline & & Vansiya Talav & 10 \\
\hline \multirow[t]{5}{*}{2} & \multirow[t]{5}{*}{ Chikhli } & Ambach & 10 \\
\hline & & Fadvel & 10 \\
\hline & & Velanpur & 10 \\
\hline & & Godthal & 10 \\
\hline & & Panikhadak & 10 \\
\hline \multicolumn{3}{|l|}{ Total } & 100 \\
\hline
\end{tabular}

Table.2 Distribution of the respondents according to their level of knowledge

$\mathbf{n}=\mathbf{1 0 0}$

\begin{tabular}{|l|l|c|c|}
\hline Sr. No. & \multicolumn{1}{|c|}{ Level of knowledge } & Frequency & Per cent \\
\hline 1. & Low (Up to 69 score) & 22 & 22.00 \\
\hline 2. & Medium (70 to 83 score) & 61 & 61.00 \\
\hline 3. & High (Above 83 score) & 17 & 17.00 \\
\hline \multicolumn{2}{|c|}{ Total } & 100 & 100.00 \\
\hline
\end{tabular}

$($ Mean=76.64)

$($ S.D. $=7.76)$

Table.3 Association between personal profile of the respondent and their knowledge level regarding low cost greenhouse technology

\begin{tabular}{|l|l|c|}
\hline \multicolumn{1}{|c|}{ Sr. no. } & \multicolumn{2}{|c|}{ Correlation co-efficient ('r' value) } \\
\hline \multicolumn{2}{|l|}{ Independent variables } & $-0.003^{\mathrm{ns}}$ \\
\hline 1. & Age & $0.217^{*}$ \\
\hline 2. & Education & $0.021^{\mathrm{ns}}$ \\
\hline 3. & Size of family & $0.223^{*}$ \\
\hline 4. & Land holding & $0.215^{*}$ \\
\hline 5. & Occupation & $0.264^{* *}$ \\
\hline 6. & Annual income & $0.117^{\mathrm{ns}}$ \\
\hline 7. & Farming experience & $0.207^{*}$ \\
\hline 8. & Social participation & $0.266^{* *}$ \\
\hline 9. & Mass media exposure & $-0.172^{\mathrm{ns}}$ \\
\hline 10. & Marketing Behaviour & $0.139^{\mathrm{ns}}$ \\
\hline 11. & Overall modernity & $0.260^{* *}$ \\
\hline 12. & Scientific orientation & $0.382^{* *}$ \\
\hline 13. & Economic motivation & $0.198^{*}$ \\
\hline 14. & Risk orientation &
\end{tabular}

*Significant at 5\% (0.196) ** Significant at 1\% (0.256) NS Non significant 
Fig.1 Association between independent variables of respondents and level of knowledge about low cost greenhouse technology

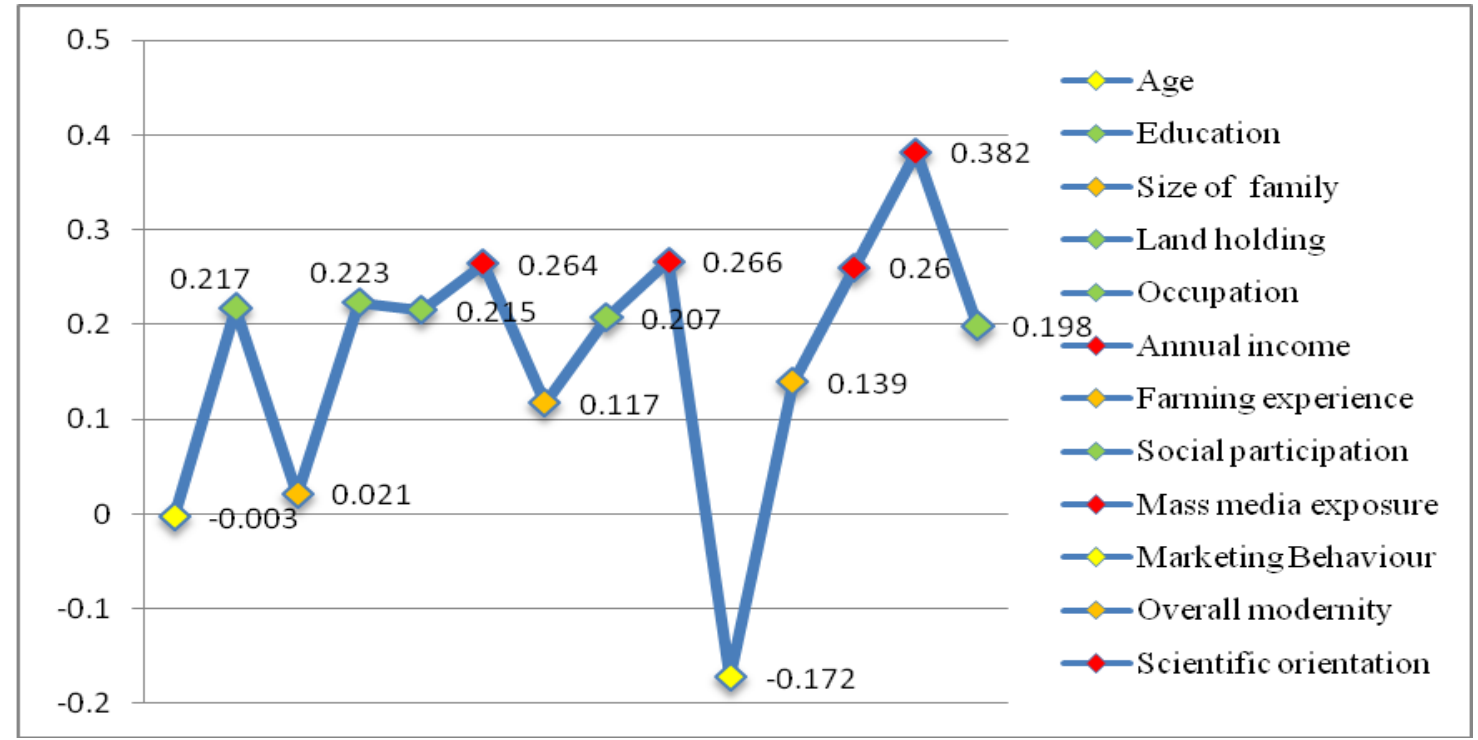

Significant Non- significant Highly significant

Fig.2 Empirical model depicting association between independent variable and level of knowledge

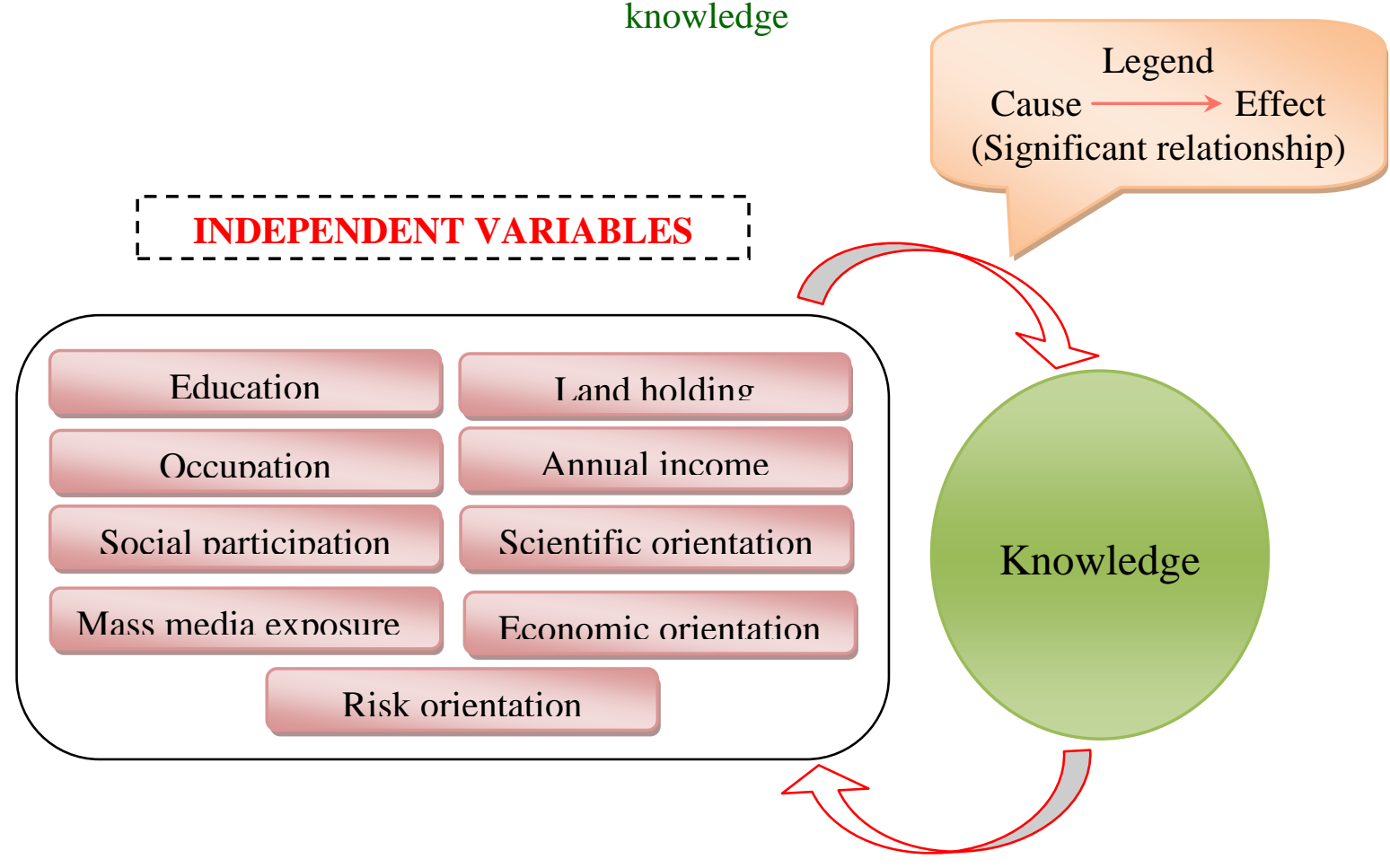

The education $(0.217 *)$, land holding $\left(0.223^{*}\right), \quad$ occupation $\left(0.215^{*}\right)$, social participation $\left(0.207^{*}\right)$ and risk orientation $(0.198 *)$ found significant and mass media exposure $\left(0.266^{* *}\right)$, scientific orientation
$(0.260 * *)$ and economic motivation $(0.382 * *)$ were highly significantly correlated with knowledge of respondents about low cost greenhouse technology. The age ($\left.0.003^{\mathrm{ns}}\right)$ and marketing behaviour $(-0.172)$ 
were negatively non-significantly correlated with knowledge of respondent about low cost greenhouse technology. From the above findings, the hypothesis $\left(\mathrm{Ho}_{2}\right)$ was partially adopted and partially rejected. This finding is in conformity with Chaudhari (2012).

In Conclusion, The low cost greenhouse play significant role in tribal region. Farmers can grow vegetable in off season and secure their livelihood. Knowledge is important attribute play vital role in the adoption of any technology. Based on the study, concluded that majority of the respondents had medium level of knowledge about low cost greenhouse. An effort made by different organization to improve knowledge of farmers is not enough in study area. This result can be improve by appropriate training and organized workshop more and more for farmers in this region. Further, Education, land holding, occupation, social participation and risk orientation found significant and mass media exposure, scientific orientation, and economic motivation were highly significantly correlated with knowledge of respondents about low cost greenhouse technology.

\section{References}

Chaudhari, P.N. 2012. Socio-economic determinates of farmer oriented technology packages for sericulture: A Field study. Indian J. Seric., 40(1): 9699.

Dhola, B.P. and Thumar, V.M. 2012. Knowledge and Constraints of Farmers towards Greenhouse. LAP Lambert
Academic Publishing, 57-60.

Inkeles, Alex. 1996. The modernization of Man, M. Weiner (Eds), Modernization basic Books, New York.

Jha, P.N. and Singh, K.N. 1970. A test to measure farmer's knowledge about high yielding variety programme. Inter discipline, 7(1): 65-67

Pandya, C.D. 2010. A Critical Analysis of Soico-Economic Status of Organic Farming Followers of South Gujarat. Unpublished Ph.D. Thesis, NAU, Navsari Campus.

Rai, S.P., Sharma, M.M. 2012. Correlates of knowledge of growers about Sugarcane production technology, Coтmu. J. Extn. Edu., 12-16.

Singh, P., Choudhary, M. and Lakhera, J.P. 2014. Knowledge and attitude farmers towards improved wheat production technology. Ind. Res. J. Ext. Edu., 14(2): 54-59.

Singha, A.K. and Baruah, M.J. 2011. Farmer's adoption behaviour in rice technology: an analysis of adoption behaviour of farmers in rice technology under different farming systems in Assam. J. Hum. Ecol., 35(3): 167-172.

Supe, S.V. 1969. Factors related to different degree of rationality in decision making among farmers, Ph.D. Unpublished Thesis, IARI, New Delhi.

Yadav, S., Prajapati, R.R. and Prajapati, M.R. 2014. Knowledge and adoption of tomato growers about improved tomato production technology. Guj. J. Ext. Edu., 16(2): 172-174.

\section{How to cite this article:}

Chauhan, C.D., M.R. Bhatt, V.S. Parmar and Charel, J.M. 2017. Knowledge of the Farmers about Low Cost Greenhouse Technology. Int.J.Curr.Microbiol.App.Sci. 6(5): 97-102. doi: http://dx.doi.org/10.20546/ijcmas.2017.605.012 